\title{
THE
}

\section{Understanding and describing users' wayfinding behavior in public library facilities}

Lauren $\mathrm{H}$. Mandel

University of Rhode Island, lauren_mandel@uri.edu

Follow this and additional works at: https://digitalcommons.uri.edu/lsc_facpubs

The University of Rhode Island Faculty have made this article openly available.

Please let us know how Open Access to this research benefits you.

This is a pre-publication author manuscript of the final, published article.

Terms of Use

This article is made available under the terms and conditions applicable towards Open Access Policy Articles, as set forth in our Terms of Use.

\section{Citation/Publisher Attribution}

Mandel, Lauren H. "Understanding and Describing Users' Wayfinding Behavior in Public Library Facilities." Journal of Librarianship and Information Science, vol. 50, no. 1, Mar. 2018, pp. 23-33, doi:10.1177/ 0961000616635243.

Available at: http://dx.doi.org/10.1177/0961000616635243

This Article is brought to you for free and open access by the Graduate School of Library and Information Studies at DigitalCommons@URI. It has been accepted for inclusion in Graduate School of Library and Information Studies Faculty Publications by an authorized administrator of DigitalCommons@URI. For more information, please contact digitalcommons-group@uri.edu. 


\title{
Understanding and describing users' wayfinding behavior in public library facilities
}

\author{
Lauren H. Mandel, PhD \\ Assistant Professor \\ University of Rhode Island \\ Graduate School of Library and Information Studies
}

Preprint

\begin{abstract}
Wayfinding is the study of how humans use a variety of informational media to orient themselves and navigate in a space, such as a library. This multi-method case study tested the applicability of a wayfinding framework developed in architecture to a public library environment. Research methods included unobtrusive observation of a random sample of users wayfinding in the facility and interviews with a convenience sample of users to discuss their wayfinding behavior. Patrons used various wayfinding behaviors in the facility, some corresponding to the framework, but other behaviors did not fit into the existing framework and not all aspects of the framework were observed or expressed. Additional research is necessary to investigate more fully the degree to which the framework validly describes how library users wayfind. Results have value for librarians, architects and interior designers, all of whom may apply findings toward their work designing facilities that are intuitive to navigate.

Keywords

Wayfinding, public libraries, library facilities, case study research, spatial information Wayfinding behavior in public libraries

Public library users face a number of information challenges when they enter the library facility. They have information needs they are trying to satisfy using library resources to locate the materials and they need spatial information to physically locate those materials. This is even true for users accessing digital resources in the library facility because in order to access digital materials, these users need to locate the physical computer lab, electric outlet, or Wi-Fi hotspot.

Information behavior is a key research area in both librarianship and information science and this concept encompasses a wide array of information behaviors, including wayfinding, a spatial information behavior. Wayfinding is the study of how humans use a variety of informational media to orient themselves and navigate in a space, whether the natural environment or the built environment, which includes cities and facilities. This paper focuses on wayfinding behavior in public library facilities.

In libraries, users rely on a library information system (e.g., the catalog or a database, librarians, etc.) to satisfy their information needs. Wayfinders also rely on an information system to satisfy their spatial information needs, the wayfinding information system (Arthur and Passini, 1992). Thus, the wayfinding information system comprises spatial information like open architecture, color-coding, or signage, and this needs to contain all information necessary to facilitate wayfinding behavior, which includes making and executing decisions as they navigate the facility. Passini's Conceptual Framework of Wayfinding (1981) details problem-specific strategies that Passini observed wayfinders using to make and execute a wayfinding decision plan, as well as two overall styles of wayfinding behavior. While Passini's framework assumes
\end{abstract}


an intended destination, which is not always true for library users, it provides a starting point for conceptualizing library user wayfinding behavior.

Improved wayfinding cues can lessen users' frustration with information-seeking problems in library facilities and ease the burden on librarians to direct users to locations that users could find for themselves if the libraries' wayfinding information systems were more intuitive and self-explanatory. This can improve the overall findability of library information and resources, helping users find information they might miss otherwise. Knowledge of how users wayfind, particularly their spatial information behavior, can provide data to improve library organizational policies related to signage (particularly the number, type and location of signs), wayfinding information systems and other information-seeking guides and tools. Finally, testing Passini's Conceptual Framework in a library environment can inform the development and expansion of this framework of human wayfinding through the lens of information behavior research to account for navigation without an intended destination.

\section{Literature review}

There is an identified need for application of wayfinding behavior research to facility design in libraries (Beecher, 2004; Hahn and Zitron, 2011; Hassanain and Mudhei, 2006; Li and Klippel, 2012; Lushington, 2002; Mattern, 2007; Schoonover and Kinsley, 2014; Stempler and Polger, 2013; Tataraka et al., 2006), especially use of such research to improve library signage systems (Bosman and Rusinek, 1997; Brown, 2002; Byam, 1979; Daniels and Eakin, 1979; Loomis and Parsons, 1979; O'Brien, 2010; Pollet and Haskell, 1979). Although a few empirical user wayfinding behavior studies have occurred in public libraries (Mandel, 2010, 2012, 2013; Beecher, 2004; Spencer and Reynolds, 1977; Veatch, 1979), library empirical wayfinding research is conducted primarily in academic libraries (Bosman and Rusinek, 1997; Eaton, 1991; Hahn and Zitron, 2011; Hassanain and Mudhei, 2006; Li and Klippel, 2012; Schoonover and Kinsley, 2014; Stempler and Polger, 2013; Tataraka et al., 2006). Public libraries serve more heterogeneous populations than academic libraries, so one cannot generalize findings about academic library user wayfinding behavior to public library facility design. Wayfinding research conducted in public libraries would benefit from a theoretical framework such as Passini's Conceptual Framework of Wayfinding (1981) because it couches wayfinding within information-seeking behavior, a concept already well understood in librarianship.

\section{Wayfinding theories}

Wayfinding includes all the perceptual, cognitive and decision-making processes necessary for people to orient and navigate in the natural or built environment (Arthur and Passini, 1992). Kevin Lynch's The Image of the City (1960) prompted a focus on wayfinding research, beginning in the external built environment (i.e., cities). Additional wayfinding research began to focus on the internal built environment (i.e., constructed facilities), such as Gordon Best's (1970) investigation of wayfinding in the Manchester (U.K.) Town Hall. This research proved valuable, as the design of improved wayfinding systems can alleviate frustration, stress and aggravation wayfinders experience when they navigate the built environment, struggling to orient themselves and find the appropriate path, or becoming lost (Arthur and Passini, 1992). Thus, architects and interior designers are urged to consider human wayfinding abilities when designing large, complex buildings to minimize wayfinding challenges, reduce functional inefficiency and increase accessibility and safety (Arthur and Passini, 1992; Best, 1970; Corlett et al., 1972; Passini, 1996). These factors are critical for public libraries as users often ignore their need for wayfinding information to locate the reference desk, OPAC station, stacks, etc. 
Passini's (1981) Conceptual Framework of Wayfinding suggests that five problemspecific wayfinding strategies and two user-specific wayfinding styles are common. Through the structured process of the wayfinding decision plan, the wayfinder can focus on individual wayfinding behavior tasks or subtasks while keeping the larger wayfinding information problem in mind (Strategy One: Dividing the Task into Manageable Parts While Keeping an Eye on the Larger Task at Hand), focus on one problem or subtask at a time (Strategy Two: Narrowing), or modify his wayfinding behavior when unforeseen problems occur (Strategy Three: Adapting and Responding). Where he can, the wayfinder relies on solutions he has used to solve prior spatial information problems (Strategy Four: Accessing One's Schemata) and he relies as best he can on the spatial information available in the environment (Strategy Five: Gathering Information and Adapting Accordingly). These strategies correspond to information-seeking strategies, for example Kuhlthau's six phases of information seeking (Raber, 2003), and are more or less observable, depending on which strategy is being used, the method employed for data collection and the honesty and openness of research subjects in describing their actions and thoughts. Strategies One and Two are akin to selecting a more or less specific topic and beginning to examine relevant information (Kuhlthau's second phase). Strategy Three relates to exploring when the users takes in information and revises his search (Kuhlthau's third phase). Strategy Five aligns with collecting information (Kuhlthau's fifth phase). There is no direct parallel between Strategy Four and Kuhlthau's phases, but Kuhlthau's fourth phase of formulating a point of view to apply to the problem could involve accessing one's schemata.

The two wayfinding styles describe people's overall systems or methods of completing wayfinding tasks; what guides their overall wayfinding behavior (Passini, 1981). Using Style One (Linear Style), the wayfinder relies on the signage system, which Passini explains as a linearly organized wayfinding support system that progresses from one location to another, guiding the wayfinder with the spatial information he needs to execute decisions along his route. Using Style Two (Spatial Style), the wayfinder relies on his spatial understanding of the setting. This is affected by his familiarity with the setting (past experience), architectural legibility of the setting (visibility and other cues) and wayfinding tools like maps and floor plans.

\section{Wayfinding research in facilities}

Like spatial problem solving and decision-making research, wayfinding research has a goal of trying to understand human spatial orientation and behavior processes. Much of this is applied research, such as field experiments and evaluations of built environments in shopping malls (Chebat et al., 2005; Dogu and Erkip, 2000; Haq and Zimring, 2003), museums (Cosley et al., 2009), office complexes (Evans et al., 1980; Hölscher et al., 2006; Ishikawa et al., 2009) and housing complexes (Gärling et al., 1983). Public libraries are large, complex built environments like shopping malls, museums, offices and housing complexes. Users enter all of these facilities seeking to fulfill specific needs (both information and other needs), and those goals distract them from paying complete attention to their spatial information needs. Therefore, these facilities should be designed so that users do not have to concentrate on navigation, but can orient and navigate intuitively while satisfying their needs (Mandel, 2012, 2013; Schoonover and Kinsley, 2014). Library facility design literature emphasizes the need to apply human wayfinding behavior research to environmental design (Beecher, 2004; Hassanain and Mudhei, 2006; Lushington, 2002; Mattern, 2007; Schoonover and Kinsley, 2014; Veatch, 1979), with a stronger emphasis on improving library signage systems (Bosman and Rusinek, 1997; Brown, 2002; Byam, 1979; Daniels and Eakin, 1979; Loomis and Parsons, 1979; Pollet and Haskell, 1979; Schoonover and Kinsley, 2014; Stempler and Polger, 2013) than architectural design issues 
(Mandel, 2010; Draper and Brooks, 1979; Li and Klippel, 2012; Loomis and Parsons, 1979; Lushington, 2002; Veatch, 1979).

If librarians, architects and interior designers understood and considered human wayfinding behavior as they planned new facilities, they would have a better chance of designing facilities that users could navigate intuitively. Library signage should be considered as systems that apply terminology, size, color and location consistently, locating signs and instructions in the proper places to assist wayfinders, using easy to understand terminology and avoiding ad hoc signs that can undermine an existing signage system (Brown, 2002; Byam, 1979). The literature also suggests how to improve the traffic flow in existing facilities by observing users to identify traffic patterns in the facility and any problems in the traffic flow (Mandel, 2010; Draper and Brooks, 1979) to ensure maximum usability of the facility (Lushington, 2002).

Others have tested the application of selected environmental design factors to public library buildings, attempting to make public libraries more useful and functional through eased human orientation in the built environment (Loomis and Parsons, 1979; Veatch, 1979). While these studies demonstrate the value of understanding human wayfinding behavior in designing public library facilities, they are over three decades old. There are more recent calls for focus on wayfinding information needs in library design (e.g., Mattern, 2007), but there is little current research into public library user wayfinding behavior beyond the dissertation research of Beecher (2004) and the author (2012).

\section{Research methods}

This paper presents selected findings from a multi-method case study into public library user wayfinding behavior guided by Passini's Conceptual Framework of Wayfinding (1981). The larger study had six research questions (Mandel, 2012, 2013), but this paper will focus on the questions related to Passini's Conceptual Framework in order to support the discussion of public library user wayfinding behavior:

1. Which of Passini's five wayfinding strategies (if any) are library users employing to navigate through the entry area of the facility, Dividing the Task into Manageable Parts While Keeping an Eye on the Larger Task at Hand, Narrowing, Adapting and Responding, Accessing One's Schemata, or Gathering Information and Adapting Accordingly?

2. Which of Passini's two wayfinding styles (if any), or some combination of both, are library users employing to navigate through the entry area of the facility, reliance on the Linear Style through usage of the facility's signage system, or reliance on the Spatial Style through the user's spatial understanding of the library setting, including the user's familiarity with, architectural legibility of and wayfinding cues and tools available in the setting?

The case study used unobtrusive observation and intensive interviews to answer these research questions.

\section{Data collection}

The research site is a two-story public library building with a second-floor mezzanine wrapping around the first floor. From the entrance to the library, users can see the circulation desk, the nonfiction stacks and the mezzanine-style second floor. However, users cannot see the rear of the library due to the 7-foot nonfiction stacks, which block the view of the children's room, reference desk, and computer lab, and they cannot see what is on the second floor. The library does not provide new users with tours of the facility or floor plans. There is a poster-size version of the floor plan on the bulletin board near the entrance. Each area of the library has a 
sign in the area, such as "Children's," "Español," "Audio \& Video," etc., but there are no signs explaining how to get from one area to another. Book stacks in all areas have end panel signage providing the range of Dewey Decimal Classification (DDC) numbers housed in that range.

The library was built in 1965, the library system had experienced substantial budget cuts resulting in reduced operating hours, and staff indicated that users struggled to locate different areas of the library easily using the existing signage, all of which combined to result in a challenging wayfinding environment for users. The library system serves an estimated 217,000 residents of a municipality in southern Florida that comprises over $80 \%$ persons of Hispanic or Latino descent and over 50\% of the population speaks English "less than very well" according to the United States Census Bureau's categorization.

Users were observed as they entered the library during randomly sampled time periods in three purposively sampled weeks, one each in summer 2010, fall 2010, and spring 2011. The mezzanine allowed the researcher to sit at the reception desk on the east end of the second floor with an unrestricted view of all areas of the first floor except those directly beneath the researcher's vantage point, one computer lab and staff offices. The researcher traced each user's route as he or she entered and navigated the library, observing the first adult user who entered the library during the sample time period $(n=285)$ and noting variables such as whether the wayfinder was alone or accompanied by another person or people, number and location of stops along the route, spatial information tools the user consulted at each stop if any and other observable wayfinding behaviors.

To understand why users engaged in specific wayfinding behaviors and solicit user input regarding the library's wayfinding system, the researcher conducted a set of intensive interviews with a convenience sample of library users $(n=16)$ in the fall of 2010. Interviews averaged 30 minutes in length and were conducted with assistance from a person who is fluent in both English and Spanish. The researcher and assistant approached users in the area of the Circulation Desk asking if they would be interested in participating in a research study, offering $\$ 20$ for participation in an interview. Librarians at the Reference Desk also sent some users to the researcher who they thought would be willing participants. All interviews occurred at a table blocked off in the front section of the library and were audio recorded, with the recordings transcribed and translated (for the Spanish interviews) and the transcriptions coded.

Interviewees ranged in age from 26 to 73, with a median age of 45 . Of the 16 interviewees, 11 were female and five were male. Half of the interviews were conducted in English $(n=8)$ and half in Spanish $(n=8)$, but most interviewees actually were bilingual or multilingual $(n=11)$. The users who participated in the interviews were asked which wayfinding styles and strategies they employed to find the places they sought in the library, why they navigated in certain ways and along certain paths, how they would prefer to navigate in the library and how they might alter the wayfinding system to improve navigation in the facility. Questions were worded to inquire about the usage of Passini's strategies and styles by employing layman's terms rather than Passini's terms, partly to attempt to validate the five strategies and two styles and partly because library users were more likely to understand layman's terms than Passini's terms. Interviewees also drew their routes on blank maps of the library to illustrate their routes.

\section{Data analysis}

Data were analyzed using geospatial analysis and content analysis. The researcher employed geospatial analysis for the routes identified from unobtrusive observation and user interviews using thematic analysis because interviewees' maps were too imprecise to map accurately in ArcGIS (discussed in Mandel 2012, 2013) and conceptual content analysis for the transcripts of 
user interviews. Interview transcripts were analyzed using conceptual content analysis in which concepts were identified and counted for frequency. No pre-defined coding scheme existed that could guide this analysis, so the coding scheme began with Passini's (1981) wayfinding strategies (1: Dividing the Task into Manageable Parts While Keeping an Eye on the Larger Task at Hand, 2: Narrowing, 3: Adapting and Responding, 4: Accessing One's Schemata, and 5: Gathering Information and Adapting Accordingly) and styles (1: Linear and 2: Spatial) and was developed iteratively as the researcher coded the interview transcripts. The resulting coding scheme had 11 main codes, with additional detailed subcodes (see Table 1 for the entire scheme). Cases where the interviewee might have been hinting at use of a strategy or style but in which the use was not clear and required conjecture were not coded as demonstrating a use of a strategy or style. After the researcher solidified the coding scheme, she conducted intra- and inter-coder reliability tests to test its reliability. Intra-coder reliability measured at $\kappa=.648$ and inter-coder reliability measured at $\kappa=.529$, indicating 'substantial' and 'moderate' agreement, respectively (Landis and Koch, 1977).

Table 1: Coding Scheme Used to Code Interviews

\begin{tabular}{|c|c|c|}
\hline Main codes & \multicolumn{2}{|l|}{ Detailed subcodes } \\
\hline \multirow[t]{3}{*}{ Strategy 1} & \multicolumn{2}{|l|}{ break problem into parts } \\
\hline & \multicolumn{2}{|l|}{ keep larger problem in mind } \\
\hline & \multicolumn{2}{|l|}{ both } \\
\hline Strategy 2 & \multicolumn{2}{|l|}{ narrow to smaller subtask } \\
\hline Strategy 3 & \multicolumn{2}{|l|}{ adapt to unforeseen problems } \\
\hline Strategy 4 & \multicolumn{2}{|l|}{ access schemata } \\
\hline \multirow[t]{3}{*}{ Strategy 5} & \multicolumn{2}{|l|}{ gather environmental information } \\
\hline & \multicolumn{2}{|l|}{ respond to environmental information } \\
\hline & \multicolumn{2}{|l|}{ both } \\
\hline Style 1 & \multicolumn{2}{|l|}{ signage system } \\
\hline \multirow[t]{6}{*}{ Style 2} & \multicolumn{2}{|l|}{ familiarity with setting } \\
\hline & \multicolumn{2}{|l|}{ architectural legibility of setting } \\
\hline & \multirow[t]{4}{*}{ wayfinding cues and tools (not signs) } & person \\
\hline & & OPAC \\
\hline & & book identifiers \\
\hline & & maps \\
\hline \multirow{4}{*}{$\begin{array}{l}\text { Route } \\
\text { descriptions }\end{array}$} & \multirow[t]{3}{*}{ qualitative: actual text of descriptions } & 1 \\
\hline & & 2 \\
\hline & & 3 \\
\hline & \multicolumn{2}{|l|}{ qualitative: my description from map } \\
\hline \multirow{7}{*}{$\begin{array}{l}\text { Reasons for } \\
\text { routes }\end{array}$} & \multicolumn{2}{|l|}{ shortest } \\
\hline & \multicolumn{2}{|l|}{ fastest } \\
\hline & \multicolumn{2}{|l|}{ straightest } \\
\hline & \multicolumn{2}{|l|}{ habit } \\
\hline & \multicolumn{2}{|l|}{ easiest } \\
\hline & \multicolumn{2}{|l|}{ to access needed materials } \\
\hline & unknown & \\
\hline
\end{tabular}




\begin{tabular}{|c|c|c|}
\hline & other reasons: specify & \\
\hline \multirow{15}{*}{$\begin{array}{l}\text { Suggested } \\
\text { changes }\end{array}$} & \multirow[t]{7}{*}{ changes to signs } & more signs \\
\hline & & fewer signs \\
\hline & & larger type \\
\hline & & larger signs \\
\hline & & use colors for differentiation \\
\hline & & other changes to signs \\
\hline & & no changes needed \\
\hline & \multirow[t]{5}{*}{ changes to pathways } & widen pathways \\
\hline & & relocate pathways \\
\hline & & make straighter pathways available \\
\hline & & other changes to pathways \\
\hline & & no changes needed \\
\hline & \multirow[t]{2}{*}{ changes to furniture } & relocate furniture \\
\hline & & other changes to furniture \\
\hline & \multicolumn{2}{|l|}{ other changes: specify } \\
\hline \multirow{13}{*}{$\begin{array}{l}\text { Reasons why } \\
\text { NOT using a } \\
\text { style/strategy }\end{array}$} & \multicolumn{2}{|l|}{ Strategy 1} \\
\hline & \multicolumn{2}{|l|}{ Strategy 2} \\
\hline & \multicolumn{2}{|l|}{ Strategy 3} \\
\hline & \multicolumn{2}{|l|}{ Strategy 4} \\
\hline & \multicolumn{2}{|l|}{ Strategy 5} \\
\hline & \multirow[t]{5}{*}{ Style 1} & signs too complicated \\
\hline & & signs not noticeable \\
\hline & & signs too small \\
\hline & & accessing schemata instead \\
\hline & & no reason given \\
\hline & \multirow[t]{3}{*}{ Style 2} & OPAC, because of time involved \\
\hline & & OPAC, no reason given \\
\hline & & person, because don't like to ask fo \\
\hline
\end{tabular}

\section{Research findings}

Strategies One and Two (Passini, 1981) were not mentioned in any interview or observed via unobtrusive observation (see Table 2 for data relating to each strategy), and Strategy Four was mentioned in interviews but not observed. The strategy mentioned most frequently was Strategy Three $(n=9)$. Two observed behaviors related to Strategy Three, making a U-turn $(n=16,5.6 \%)$ and weaving to avoid an obstacle $(n=5,1.8 \%)$ both of which indicated that the wayfinder was adapting to unforeseen problems and responding accordingly. Other strategies mentioned with some frequency include Strategy Four $(n=5)$ and Strategy Five $(n=5)$, which manifested in the observed behavior of looking around $(n=40 ; 14.0 \%)$, a mechanism to gather information.

\section{Table 2: Data showing use of Passini's strategies}

\begin{tabular}{lll}
\hline Strategy & Examples from transcripts & Observed behaviors \\
\hline One & None & None \\
\hline
\end{tabular}




\begin{tabular}{|c|c|c|}
\hline Two & None & None \\
\hline \multirow[t]{3}{*}{ Three } & $\begin{array}{l}\text { 'they moved the biographies cause they used to be here } \\
\text { and now they're here, cause they used to be here and now } \\
\text { they're here cause that took me like } 10 \text { minutes and I } \\
\text { asked a guy' }\end{array}$ & $\begin{array}{l}\text { Making a u-turn }(n=16 \text {; } \\
5.6 \%)\end{array}$ \\
\hline & $\begin{array}{l}\text { 'Ah, then, if I see that this is crowded then I do, these are } \\
\text { the stairs' }\end{array}$ & \multirow[t]{2}{*}{$\begin{array}{l}\text { Weaving to avoid an } \\
\text { obstacle }(n=5 ; 1.8 \%)\end{array}$} \\
\hline & $\begin{array}{l}\text { 'if I don't find, um, by looking for it, then I go back and I } \\
\text { ask at the desk' }\end{array}$ & \\
\hline \multirow[t]{3}{*}{ Four } & $\begin{array}{l}\text { 'Um, I think I cannot go this way because, yeah, the way } \\
\text { to go out. So I think there are, kind of, devices that don't } \\
\text { allow me to go this way' }\end{array}$ & \multirow[t]{3}{*}{ None } \\
\hline & $\begin{array}{l}\text { 'in the next year, I followed the same path because I } \\
\text { already knew where the taxes were' }\end{array}$ & \\
\hline & $\begin{array}{l}\text { 'If you couldn't find, you could look it up and then next } \\
\text { time you remember' }\end{array}$ & \\
\hline \multirow[t]{3}{*}{ Five } & 'For there, I just look around' & \multirow{3}{*}{$\begin{array}{l}\text { Looking around }(n=40 ; \\
14.0 \%)\end{array}$} \\
\hline & $\begin{array}{l}\text { 'if I see that this is crowded then I do, these are the stairs, } \\
\text { uh this is an aisle right? Yeah. Ok, I do this [draws on } \\
\text { map]. This is my alternative.' }\end{array}$ & \\
\hline & $\begin{array}{l}\text { 'I mean, if anything, I just have to look up and that'll tell } \\
\text { me which direction to go... biography, or other sections' }\end{array}$ & \\
\hline
\end{tabular}

Interviewees indicated that Passini's two wayfinding styles (1981) guided their spatial information seeking process with far greater frequency than they indicated use of the five strategies. Table 3 shows examples of matches between interviewees' responses, observed behaviors and Passini's styles. Nearly all interviewees mentioned that Style One: Linear (the signage system) or Style Two: Spatial (wayfinding cues and tools) guided their overall wayfinding behavior. Style Two was mentioned as a guiding system more frequently $(n=16)$ than Style One $(n=9 ;)$.

Table 3: Data showing use of Passini's styles

\begin{tabular}{lll}
\hline Style & Examples from transcripts & Observed behaviors \\
\hline One & $\begin{array}{l}\text { 'They have signs here. That indicate more or less, uh, } \\
\text { where the, all types of literature are' }\end{array}$ & $\begin{array}{l}\text { Looking at a sign }(n=4 ; \\
1.4 \%)\end{array}$ \\
\cline { 2 - 3 } & $\begin{array}{l}\text { 'I look at the signs... the signs are very helpful for me to } \\
\text { find the books' }\end{array}$ & \\
\cline { 2 - 3 } & 'I look at the signs for the areas' & $\begin{array}{l}\text { Got directions from } \\
\text { someone }(n=16 ; 5.6 \%)\end{array}$ \\
\hline Two & 'I just went and, and asked the guy' & $\begin{array}{l}\text { Accompanied by staff } \\
(n=7 ; 2.5 \%)\end{array}$ \\
\cline { 2 - 2 } & $\begin{array}{l}\text { 'Or I would look it up [referring to online public access } \\
\text { catalog] by the title or the theme of the book' }\end{array}$ & \\
\cline { 2 - 2 } & 'I do use the maps' &
\end{tabular}

Style One, or use of the library's signage system, seemed to be guiding interviewees' wayfinding less frequently $(n=9)$ than Style Two $(n=16)$, despite the preponderance of signs in the library (for more discussion of the library's signage system, see Mandel, 2012) and the 
emphasis on signage in librarianship literature. Seven interviewees noted specifically that they did not use Style One to navigate the library and looking at a sign was an infrequently observed behavior $(n=4 ; 1.4 \%)$. Only about half of interviewees who said they did not use signs provided a clear reason, such as 'Um, the signs are small. The signs are really small', 'No... I know there are some [signs] in the aisles and stuff like that, like one, two, three, four, five, six, or whatever, some type of area, but I just don't... It's too complicated. I would have to think a lot', 'I don't know... oh, yeah, but they're part of the background, like the art... You see them, but you don't really... notice' and 'I don't need the signs to help me find the books... I know where all the books are at'. The interviewees who gave no specific reason were still very clear that the signs were not useful to them, saying 'I don't read the signs', 'The signs wouldn't help me guide me where I could find the book' and 'Those [call number signs] are not useful'.

Interviewees were more likely to mention being guided by Style Two in this facility $(n=16)$. All sixteen interviewees mentioned being guided by various wayfinding cues and tools, but only one interviewee mentioned being guided by familiarity with the setting and architectural legibility of the setting (the same interviewee mentioned using both of these aspects of Style Two). For purposes of this research, the researcher broke down wayfinding cues and tools into four categories based on the interviews: person, online public access catalog, book identifiers (such as author, title and call number) and maps. Three interviewees mentioned using the online public access catalog and only one mentioned using a map. Person $(n=15)$ and book identifiers $(n=10)$ were by far the aspects of Style Two guiding the largest number of interviewees in the facility. Getting directions was a frequently observed wayfinding behavior $(n=16 ; 5.6 \%)$ and a second behavior, being accompanied by a staff member $(n=7,2.5 \%)$, also corresponded to this style. Most of these interviewees were asking for help from library staff, for example 'I ask [one of the children's librarians], or one of the ladies [at the circulation desk] that I've known for a while' and 'I ask a librarian if there's something of particular interest that I have'. Some interviewees had used the call numbers, saying 'I use the coding... the coding on the end of the sections [referring to call numbers on stack ends]' and 'Usually, yeah I match, uh, whatever the computer says [referring to the call numbers] to the code [referring to spine labels with call numbers]'. However, use of authors, titles and subjects seemed more prevalent.

\section{Discussion}

\section{Use of Passini's wayfinding strategies and styles}

In general, this research found limited use of Passini's five wayfinding strategies and greater use of the two styles. Unobtrusive observation and intensive interviews were unable to identify use of wayfinding Strategy One, Dividing the Task into Manageable Parts While Keeping an Eye on the Larger Task at Hand, and Strategy Two, Narrowing, to any significant degree. Because users would have employed these wayfinding behaviors cognitively, they were not visible to an unobtrusive observer, and the interviewees seemed to be unable to articulate or remember use of these behaviors, rendering both methods ineffective for investigating use of these strategies.

As one case study is insufficient to discount these strategies entirely, additional research is necessary. One possible mechanism for investigating use of Strategies One and Two would be to conduct research that includes a think-aloud protocol while users complete a wayfinding task, such as during cognitive mapping tests ( $c f$. Kitchin, 1997) or a quasi-experiment where users are given wayfinding tasks to complete ( $c f$. Eaton, 1991; Hahn and Zitron, 2011; O’Neill, 1991).

Such methods would temper the difficulties in observing or asking people to remember cognitive 
processes by having people describe their thoughts as they conduct the wayfinding tasks and think about what they are doing to solve the wayfinding problem.

Strategies Three and Four were mentioned by interviewees, but difficult to observe. Interviewees mentioned using Strategy Three: Adapting and Responding to make and execute decisions more than any of the other five wayfinding strategies. Much of what they said fell into the category of trying to do one thing, encountering an obstacle and having to do something else to accomplish one's ultimate goal. This strategy could not be observed physically during the unobtrusive observation, but it possibly explained observed behaviors such as making U-turns and weaving to avoid obstacles, which were observed in about $7 \%$ of cases. Strategy Four: Accessing One's Schemata represented a cognitive process that interviewees did say they had employed while wayfinding in the library, but this is not an observable behavior. Several interviewees mentioned doing things from habit or because they had learned how to solve a wayfinding problem previously so they used the same solution during subsequent library visits. This is a useful strategy for wayfinding, but relying on habit can have a downside when schemata are not updated to reflect environmental changes. For example, two interviewees said they could only enter the facility through the east door and exit through the west door, but both doors were made entry and exit in 2007 (three years prior to the interviews), indicating they needed to update their schemata in order for this to be an effective wayfinding strategy.

Strategy Five: Gathering Information and Adapting Accordingly was mentioned by only five interviewees but was observed more than any other observed wayfinding behavior. This was observed as looking around, which was noted in about $14 \%$ of cases. Looking around is a physical manifestation of collecting information, not adapting to it, so it is likely that even more wayfinding behaviors related to this strategy. Two interviewees, in fact, mentioned gathering information, and three interviewees mentioned both collecting information and adapting to it, so it seems some library users might have been engaging in only half of this strategy. This cannot be said with certainty, however, as interviewees might have been able to recall using only the first half of the strategy even if they actually had used both components of the strategy while wayfinding. Here again, a think aloud protocol might be able to delve further into user wayfinding behavior.

In addition to the possibility that Passini's wayfinding strategies were not being employed by the majority of library users as they navigated the facility, observed users and interviewees indicated using other wayfinding behaviors that do not align with Passini's Conceptual Framework of Wayfinding: following or joining another person, giving directions, appearing to be lost or wandering, waiting for another person and weaving around no discernable obstacle. Waiting for someone else and weaving without a discernable obstacle may correlate to information-seeking behaviors that assume no intended destination at the outset of the wayfinding task, such as serendipitous information-seeking. Further research is needed to gather more data on the degree to which library users employ Passini's strategies and the other wayfinding behaviors that do not fit in the existing framework, as well as to help determine if the model should be modified to accommodate these other behaviors.

This research found more frequent use of Passini's two wayfinding styles than of his five strategies to make and execute decisions. Of concern, however, was that the limited observation of uses of Style One coincided with findings that the library contained excessive signage (Mandel, 2012) and that about half of interviewees were dissatisfied with the library's existing signage. Although one might think from the focus on signage in the library design literature that a signage system would be used more often than architectural legibility or other wayfinding cues 
and tools, in this library, the Style One seems to be guiding users' overall wayfinding systems less frequently than Style Two.

For users who were guided by signs (primarily based on data from the interviews), they were using a wide variety of library signs, including call number signage that could have been difficult to decipher. Slightly fewer than half of interviewees, however, specifically noted that they did not use signs in the library. Reasons varied for this lack of use, but several interviewees indicated problems with the signage such as the signs were too complicated, too unnoticeable, or too small to use effectively. Given that the library had over 1,300 signs at any time (Mandel, 2012), this remark was of particular concern, both to the researcher and to the library wayfinding and signage expert employed in the expert review discussed elsewhere (Mandel, 2012). What was happening in this library was that people seemed to be using other wayfinding cues and tools, rather than Style One. The most frequently relied upon wayfinding tool was People, mentioned by nearly all of the interviewees; this was also the most frequently used strategy in Schoonover and Kinsley's study of university library users (2014). Use of architectural legibility and familiarity with the setting were mentioned infrequently, but these might have been used more often than the results indicated given that interviewees seemed to struggle recalling how they had been wayfinding in the library.

The literature specifically warns against excessive signage (Eaton, 1991; Marks and Findley, 2006) and indicates signage cannot overcome fundamentally confusing, complex, or inaccessible architecture (Arthur and Passini, 1992; Dogu and Erkip, 2000; Eaton, 1991; Passini, 1996). Li and Klippel describe an architecturally confusing library in which users struggle to orient and navigate despite multiple efforts to improve signage (2012). In discussing the wayfinding success of an academic library, Marks and Findley said that the wayfinding success was attributable partially to the fact that signage "is adequate but has not been overdone to the point of there being so many signs that people don't see them" (2006: 17). A way to overcome this excessive signage would be to view the signage as a complete system. Brown (2002), Byam (1979), Mallery and DeVore (1982), Selfridge (1979), Spencer and Reynolds (1977) and the signage expert consulted for this research all recommended use of a signage system rather than disconnected signs, and this is part of Tataraka et al.'s recommendations for a library where many users fail to find the information they seek (2006). The signage expert was shocked by the number of signs in the library, although she noted that she had found excessive signs in many public libraries and it had been difficult to prove to librarians the adverse effects of excessive signage on user wayfinding.

Overall, it seemed that library users were guided by Passini's wayfinding styles and, to a lesser extent, his strategies. The styles are more over-arching descriptions of user wayfinding behavior; people rely on Style One (the signage system), Style Two (architectural cues, familiarity with the setting, etc.), or sometimes both. This research bears out Passini's thinking with regard to the two styles. Library users were observed to utilize both styles in guiding their wayfinding methods, and interviewees stated they used both styles with some regularity. Additional research is necessary to investigate use of the cognitive processes of Strategies One and Two, which are difficult to articulate and observe, and to determine if the newly observed behaviors would help researchers adapt Passini's Conceptual Framework of Wayfinding to the spatial information needs and wayfinding behaviors of library users.

Passini's Conceptual Framework of Wayfinding in library user wayfinding behavior research 
Passini's Conceptual Framework of Wayfinding (1981) was based on the goal of designing a facility that guides users to known destinations. However, it might not be $100 \%$ effective for libraries where some users do not have known destinations and are intentionally browsing the collection or facility. In addition to the literature on serendipitous information seeking ( $c f$. Foster and Ford, 2003) that demonstrated the occurrence of this type of library information-seeking and studies that investigated a variety of types of library user information seeking behavior ( $c f$. Björneborn, 2008), the research described in this paper found some users appeared to be lost, wandering, or bouncing back and forth between service desks (e.g., from the circulation desk to the reference desk and back to the circulation desk or from the reference desk to the computer help desk and back to the reference desk). All of this behavior indicated users who did not necessarily have a known destination as they entered and navigated the facility.

This does not mean that those users did not have valid spatial information needs. In fact, Lynch said that it is valuable to wander a labyrinth, as long as there is no fear of becoming totally and irrevocably lost (1960). Library users engaging in serendipitous information seeking or other browsing-type behavior still require wayfinding guidance, it just might be different guidance than what would be needed by users with known destinations. For example, a user who knew he intended to locate fiction books would require guidance to get him from the front door to the fiction section, but a user who did not know what kind of books he intended to find would need guidance from the front door to a variety of areas to help him get an idea of what, exactly, he was looking for. Researching this type of information-seeking behavior might be guided by serendipitous information seeking research (Foster and Ford, 2003) and retail design principles that seek to intentionally guide customers to destinations pre-determined by facility managers and corporate executives (Underhill, 1999).

Passini (1981) does not account for wayfinding without an intended destination and his framework seems to assume a lone wayfinder. But both navigating without an intended destination and navigating in pairs or groups are types of wayfinding that occur in libraries, so there is a question of whether Passini's framework, as it stands, is sufficient to describe user wayfinding behavior in a library. Perhaps it is not and, the framework needs to be modified to account for wayfinding with and without an intended destination. Such modification might include the additional wayfinding behaviors identified by this research as part of the strategies and/or styles: following or joining another person, giving directions, appearing to be lost or wandering, waiting for another person and weaving with no discernable obstacle. There could be a third style incorporated into the framework, serendipitous wayfinding or a new strategy, following or joining. Any such modifications would need to be based on additional, empirical research guided by Passini's framework, as well as the findings here that suggest additional styles and strategies.

\section{Areas for future research}

The potential list of research questions for wayfinding in public library facilities includes:

1. What facilitates user wayfinding most: signs, maps, tours, or verbal instructions?

2. When users are seeking information serendipitously, how do they interact with the facility's wayfinding information system (if at all)?

3. Why are some areas of a facility experiencing higher levels of traffic than other areas and how can this information be leveraged to guide user wayfinding?

4. Do users, in fact, prefer straighter and more direct paths or are they using these paths because they see others using them? 
5. To what degree are users stopping at specific places for specific reasons, what are those reasons and to what extent does this affect their overall wayfinding behavior?

Future research could incorporate use of additional technologies for recording user wayfinding behavior, such as asking users to wear RFID tags, carry GPS-enabled smart phones with a special application, or use QR code readers on smart phones to "check in" to specific places as they navigate a facility.

Future research into Passini's Conceptual Framework of Wayfinding is of particular interest to the researcher as she believes this frame has the potential to be widely applicable to the design of all types of public use facilities, although research is needed to investigate whether Strategies One and Two are valid descriptors of library users' wayfinding behavior. Also, as this research is merely a first step in exploring the accuracy with which the framework explains user wayfinding behavior in public libraries, considerable work remains with regard to testing this framework in order to develop propositions and move it further into becoming a theory. A beginning list of areas to explore follows:

1. If users were given a wayfinding task to complete in a facility and asked to think aloud while completing the task, which (if any) of Passini's styles or strategies would guide their wayfinding as they complete the task? Does the type of task affect which of the styles guide wayfinding behavior and which of the five strategies wayfinders use to make and execute decisions? What if they were asked to browse the facility for something that peaked their interest (i.e., serendipitous information discovery), then which (if any) of Passini's styles or strategies would guide their wayfinding as they browsed?

2. To what extent would an experiment using think aloud protocol show use of strategies one and two, as well as the other three strategies and two styles of wayfinding?

3. If the styles and strategies were explained to wayfinders, to what degree would they understand what the styles and strategies mean and subsequently be able to articulate their use?

4. To what degree are users employing any of the wayfinding behavior observed in this research that do not fit in Passini's Conceptual Framework of Wayfinding: following or joining another person, giving directions to another person, appearing to be lost or wandering, waiting for another person and weaving with no discernable obstacle? When users employ these behaviors, are they seeking information specifically or serendipitously?

\section{Conclusion}

Users navigated the library using a variety of wayfinding behaviors, some of which correspond to Passini's styles and strategies of wayfinding (1981), but the research did not demonstrate that people were using either Strategy One: Dividing the Task into Manageable Parts While Keeping an Eye on the Larger Task at Hand or Strategy Two: Narrowing to make and execute wayfinding decisions. Users did seem to be guided by Styles One and Two and to be using Strategy Three: Adapting and Responding, Strategy Four: Accessing One's Schemata and Strategy Five: Gathering Information and Adapting Accordingly.

This research also concluded that a significant amount of work remains to be done with regard to applying Passini's Conceptual Framework of Wayfinding to library wayfinding. This framework holds potential for explaining public library user wayfinding behavior, but additional research is necessary to investigate more fully the degree to which the styles and strategies are valid descriptors of how users are wayfinding in public libraries. Such research is of vital importance to a field that is continually under pressure to justify its value to the community. 
Easier-to-navigate facilities can result in greater user satisfaction with and appreciation for public library facilities, hopefully leading to continued support for their existence and maintenance.

\section{References}

Arthur P and Passini R (1992). Wayfinding: People, Signs, and Architecture. New York: McGraw-Hill.

Mandel LH (2010). Toward an understanding of library patron wayfinding: observing patrons' entry routes in a public library. Library and Information Science Research, 32(2): 116130.

Mandel LH (2012). Lost in the labyrinthine library: a multi-method case study investigating public library user wayfinding behavior. PhD Thesis, Florida State University, Tallahassee, Florida, U.S.

Mandel, LH (2013). Finding their way: how public library users wayfind. Library and Information Science Research, 35(4): 264-271.

Baskaya A, Wilson C and Özcan Y (2004). Wayfinding in an unfamiliar environment: different spatial settings of two polyclinics. Environment and Behavior, 36(6): 839-867.

Beecher AB (2004) Wayfinding tools in public library buildings: a multiple case study. PhD Thesis, University of North Texas, Denton, Texas, U.S.

Best G (1970) Direction-finding in large buildings. In: Architectural psychology: proceedings of the conference held at Dalandhui University of Strathclyde, 28 February - 2 March 1969 (ed DV Canter), pp. 72-75. Cambridge: W. Heffer and Sons.

Björneborn L (2008). Serendipity dimensions and users' information behavior in the physical library interface. Information Research, 13(4): paper 370. Available at: http://www.informationr.net/ir/13-4/paper370.html

Bosman E and Rusinek C (1997) Creating the user-friendly library by evaluating patron perceptions of signage. Reference Services Review, 25(1): 71-82.

Brown CR (2002) Signs and wayfinding. In: Brown CR Interior Design for Libraries: Drawing on Function and Appeal. Chicago: American Library Association, pp. 87-95.

Byam MS (1979) An approach to public library signage. In: Pollet D and Haskell PC (eds) Sign Systems for Libraries: Solving the Problem. New York: R. R. Bowker, pp. 137-144.

Chebat JC, Gélinas-Chebat C and Therrien K (2005) Lost in a mall, the effects of gender, familiarity with the shopping mall and the shopping values on the shoppers' way finding processes. Journal of Business Research, 58(11): 1590-1598.

Corlett EN, Manenica I and Bishop RP (1972) The design of direction finding systems in buildings. Applied Ergonomics, 3(2): 66-69.

Cosley D, Baxter J, Lee S, Alson B, Nomura S, Adams P, Sarabu C and Gay G (2009) A tag in the hand: supporting semantic, social, and spatial navigation in museums. In: Proceedings of CHI 2009, pp. 1953-1962.

Daniels B and Eakin G (1979) Coordinating graphics and architecture. In: Pollet D and Haskell PC (eds) Sign Systems for Libraries: Solving the Problem. New York: R. R. Bowker, pp. 181-185.

Dogu U and Erkip F (2000) Spatial factors affecting wayfinding and orientation: a case study in a shopping mall. Environment and Behavior, 32(6): 731-755.

Draper J and Brooks J (1979) Directing traffic. In: Draper J and Brooks J Interior Design for Libraries. Chicago: American Library Association, pp. 26-39.

Eaton G (1991) Wayfinding in the library: book searches and route uncertainty. Reference Quarterly, 30(4): 519-527. 
Evans GW, Fellows J, Zorn M and Doty K (1980) Cognitive mapping and architecture. Journal of Applied Psychology, 65(4): 474-478.

Foster A and Ford N (2003) Serendipity and information seeking: an empirical study. Journal of Documentation, 59(3): 321-340.

Gärling T, Lindberg E and Mantyla T (1983) Orientation in buildings: effects of familiarity, visual access, and orientation aids. Journal of Applied Psychology, 68(1): 177-186.

Hahn J and Zitron L (2011) How first-year students navigate the stacks: implications for improving wayfinding. Reference \& User Services Quarterly, 51(1): 28-35.

Haq S and Zimring C (2003) Just down the road a piece: the development of topological knowledge of building layouts. Environment and Behavior, 35(1): 132-160.

Hassanain MA and Mudhei AA (2006) Post-occupancy evaluation of academic and research library facilities. Structural Survey, 24(3): 230-239.

Hertel K and Sprague N (2007). GIS and census data: tools for library planning. Library Hi Tech, 25(2), 246-259.

Hölscher C, Meilinger T, Vrachliotis G, Brösamle M and Knauff M (2006) Up the down staircase: wayfinding strategies in multi-level buildings. Journal of Environmental Psychology, 26(4): 284-299.

Ishikawa T, Murasawa K and Okabe A (2009) Wayfinding and art viewing by users of a mobile system and a guidebook. Journal of Location Based Services, 3(4): 277-283.

Kitchin RM (1997) Exploring spatial thought. Environment and Behavior, 29(1): 123-156.

Landis JR and Koch GG (1977) The measurement of observer agreement for categorical data. Biometrics, 33(1), 159-174.

Li R and Klippel A (2012) Wayfinding in libraries: can problems be predicted? Journal of Map \& Geography Libraries, 8(1): 21-38.

Loomis RJ and Parsons MB (1979) Orientation needs and the library setting. In: Pollet D and Haskell PC (eds) Sign Systems for Libraries: Solving the Problem. New York: R. R. Bowker, pp. 3-15.

Lushington N (2002) Libraries Designed for Users: a 21st Century Guide. New York: NealSchuman.

Lynch K (1960) The Image of the City. Cambridge, Mass: Massachusetts Institute of Technology Press.

Mallery MS and DeVore RE (1982) A Sign System for Libraries. Chicago: American Library Association.

Marks K and Findley T (2006) Lied Library at the University of Nevada, Las Vegas: postconstruction thoughts. Library Hi Tech, 23(1): 16-21.

Mattern S (2007) Form for function: the architecture of new libraries. In: Mattern S The New Downtown Library: Designing with Communities. Minneapolis, Minn: University of Minnesota Press, pp. 55-83.

O'Brien D (2010) Wayfinding and signage. In: Bates MJ and Maack MN (eds) Encyclopedia of Library and Information Sciences (3rd ed). Boca Raton, Fla: CRC Press, pp. 5593-5614.

O'Neill,MJ (1991) Evaluation of a conceptual model of architectural legibility. Environment and Behavior, 23(3): 259-284.

Passini R (1981) Wayfinding: a conceptual framework. Urban Ecology, 5(1): 17-31.

Passini R (1996) Wayfinding design: logic, application and some thoughts on universality. Design Studies, 17(3): 319-331. 
Pollet D and Haskell PC (1979) Introduction. In: Pollet D and Haskell PC (eds) Sign Systems for Libraries: Solving the Problem. New York: R. R. Bowker, pp. ix-xii.

Raber D (2003). The Problem of Information: an Introduction to Information Science. Lanham, MD: Scarecrow.

Schoonover D and Kinsley KM (2014) Stories from the stacks: students lost in the labyrinth. Journal of Access Services, 11(3): 175-188.

Selfridge KM (1979) Planning library signage systems. In: Pollet D and Haskell PC (eds) Sign Systems for Libraries: Solving the Problem. New York: R. R. Bowker, pp. 49-67.

Spencer H and Reynolds L (1977) Directional Signing and Labeling in Libraries and Museums: a Review of Current Theory and Practice. London: Readability of Print Research Unit, Royal College of Art.

Stempler AF and Polger MA (2013) Do you see the signs? Evaluating language, branding, and design in a library signage audit. Public Services Quarterly, 9(2): 121-135.

Tataraka A, Larsen D, Olson T and Kress N (2006) Wayfinding in the library: usability testing of physical spaces. In: Proceedings of the ARL library assessment conference: building effective, sustainable, practical assessment (eds F DeFranco, S Hiller, LJ Hinchcliffe, K Justh, M Kyrillidou, J Self and J Stein), Charlottesville, Virginia, September 25-27, 2006. Washington, DC: Association of Research Libraries.

Underhill P (1999) Why We Buy: the Science of Shopping. New York: Simon \& Schuster. United Nations, Department of Economic and Social Affairs, Statistics Division (2000) Handbook on geographical information systems and mapping. New York: United Nations.

Veatch JL Jr (1979) Library architecture and environmental design: the application of selected environmental design factors to the planning of public library facilities. $\mathrm{PhD}$ Thesis, The Florida State University, Tallahassee, Florida, U.S. 